\title{
English Language Teaching and Learning in Bangladesh: CLT Perspective
}

\author{
Antara Basak \\ Lecturer, English Daffodil International University Dhaka, Bangladesh
}

\begin{abstract}
Bangladeshi students study English grammar as a compulsory subject from primary to tertiary level of education. Students are taught fixed grammatical rules in different education levels as mentioned in the syllabus. The intention of this paper is to show the status of teaching English grammar in Bangladesh and thereby to discover whether there is any effect of communicative method in teaching English grammar in the mentioned context. The main observations from this study are: Teachers use the grammar translation method in teaching and rarely have exposure to communicative approach. New teaching methods are rarely introduced. Grammatical rules are taught deductively, through direct demonstration in the classroom. Lack of contextual interpretation of grammatical rules is common. Students memorize the exam oriented rules of English grammar. No interesting communicative practices are done. Moreover awareness regarding teaching and learning English grammar in an effective communicative method is not visible.
\end{abstract}

Keywords: Teaching Grammar, Traditional Method, Language Skill, Communication.

\section{Introduction}

English is one of the most used languages in the world. English is taught and learnt throughout the world because of its international status,. English is used as a second language in Bangladesh. Bangladeshi students study English from the primary to the tertiary level of education as a compulsory subject. Grammar is considered to be the basis of learning and using a language. Without learning grammar it is not possible to use a language appropriately and correctly.

\section{What Is Grammar?}

The easiest and simplest answer of this question is grammar is a set of rules of a particular language. Different linguistists have defined grammar in different ways. Thornbury (1999) defines grammar saying that grammar is partly the study of the structures that are possible in a language. In this sense grammar is the description of the rules that govern how the sentences of a language are formed. To define grammar, Islam (1997) writes that grammar is a set of rules of a specific language. Every language has some peculiarities. They are established by usage and grammar is a direction to such usage. Islam mentions Chomsky's words cited by Palmer (1971, p.3), "Grammar is seen as a device that...... specifies the finite set of well formed sentences and assigns to each of them one or more structural description."

Penny Ur (1988, p.4) says, "Grammar may be roughly defined as the way a language manipulates and combines words in order to form longer units of meaning....................There is a set of rules which govern how units of meaning may be constructed in any language: we may say that a learner who 'knows grammar' is one who has mastered and can apply these rules to express him or herself in what would be considered acceptable language forms."

Grammar is the structural foundation of users' ability to express them. If they are aware of grammar, they can monitor the meaning and effectiveness of the way to use language.

\section{Reasons For Teaching And Learning Grammar}

Grammar is an essential part of language. Grammar is needed to use, to understand and to master a language. Language is very important as human being cannot live without language. As Crystal (1995, p. 119) writes, "To understand the linguistic dimension of our existence would be no mean achievement. And grammar is the fundamental organizing principle of the language. Our grammatical ability is extraordinary.......... There is no limit to what we can say or write, get all of this potential is controlled by a finite number of rules. Nevertheless, our language can let us down, we encounter ambiguity, imprecision and unintelligible speech or writing. To deal with these problems, we need to put grammar under the microscope, and work out what went wrong."

Learning English grammar provides a basis for learning other languages. After studying grammar one can be more alert to the strength, flexibility and variety of the language and thus can be in a better position to use it and evaluate others' use of it. 
The students of Bangladesh learn English as their L2. In case of learning L2, the environment is much different than L1 acquisition. Without knowing the grammatical rules of using English students won't be able to use it with confidence and perfection.

\section{Different Methods Of Teaching Grammar}

There are different views about the methods of grammar teaching. These views have emerged from the history of the method of teaching grammar. Thornbury (1999) gives details of different ways to teach grammar as related to different methods of language teaching.

The first one is Grammar Translation Method which took grammar as the starting point of instruction. This is a very common method of teaching grammar which is followed in most of the grammar classes by the teachers. Next comes Direct Method that emerges in the mid to late nineteenth century. It claimed to be a 'natural' method. According to Thornbury, the learners picked up the grammar in much the same way as children pick up the grammar of their mother tongue, simply by being immersed in language. Another method is Audio-lingual Method in which language is considered as a form of behavior to be learned through the formation of correct habits.

In the 1970s Communicative language teaching emerged with the development in the new science of sociolinguistics. Communicative competence consists of more than simply the knowledge of the rules of grammar. Thornbury suggests that explicit attention to grammar rules was not contrary to communicative practice. He also quoted Chomsky's claim that language was rule governed and this seemed to suggest that explicit rule-giving may have a place after all. By this time, CLT was being developed and Chomsky's belief was readily absorbed into it. Grammar rules appeared in course books at the expenses of communicative practice.

About grammar teaching there are three other important points which are practice, error and error correction. Practice is very essential to be fluent in using grammar. While practicing students make errors and the correction of errors makes their learning effective.

Penny Ur (1991, p.83) says, "The aim of grammar practice is to get students to learn the structures so thoroughly that they will be able to produce them correctly on their own." He suggests that the teachers should help their students to make a 'leap' from form focused accuracy work to fluent and acceptable performance, by providing a 'bridge'. A variety of practice can make them familiar with the structures in context, giving practice both in form and communicative meaning.

About the teaching of grammar in classroom Antony (1995) suggests some steps which a teacher should follow. After introducing the topics a teacher can make them do an exercise in pairs, then discuss the answer in class. The teacher may, then, present the first aspect of grammatical focus using examples from the book, encouraging constant questions from the class. The next step can be to have students do the associated exercises in class in pairs, looking up the answers themselves in the answer key when they have finished discussing the results. Teacher can facilitate the task by wandering from pair to pair, making himself available for questions without instructing on the activity unless specifically asked. After the task has been completed, questions can be asked from the students regarding the exercise or problems can be focused which the teacher noticed during the pair work. Next point should be presented having allowed plenty of time for students to digest the material before moving on.

\section{How Grammar Should Be Taught?}

Grammar teaching means different things to different people. To some people, grammar teaching is simply teaching a grammar syllabus. Outside the syllabus there is no mention of grammar in the classroom at all. To others, it is teaching a communicative syllabus and dealing with grammar questions that arise in the course of doing communicative activities. It is known as covert grammar teaching. But traditionally, grammar teaching means teaching a grammar syllabus and explicitly presenting the rules of grammar, using grammar terminology. This is known as overt grammar teaching.

About the status of grammar Thornbury (1999) mentions that the purpose of the introduction of CLT is to give emphasize on experimental learning and purely communicative goals. In case of CLT there is tendency to equate grammar with accuracy. In this regard Thornbury also quoted Prabhu's idea about deep-end version of CLT which was hostile to explicit grammar teaching. But this condition was relatively short lived. In this theoretical perspective it seemed to have little or no influence on global classroom practice.

In this regard Scott's argument is that without attention to grammatical form the learners cannot progress beyond the most basic level of communication. He also explains that grammar should not be the goal of teaching and the focus on form alone is not enough. The goal of the communicative movement includes not only grammar but also a focus on meaning. Thornbury (1999, p.25) says, "Communicative competence is best achieved through communicating, through making meaning, and that grammar is a way of tidying these meanings up." 
Ellis (1994) also expresses his view about implicit and explicit grammar teaching. In case of implicit treatment learners are required to induce rules from examples given to them. On the other hand, in case of explicit treatment learners are given a rule which they then practice using.

In CLT a teacher pays more attention to enable students to work with the target language during the lesson and communicate in it by the end of it. What makes this kind of lesson different from the traditional is that the teacher tries to make the language used in the lesson real and true. The teacher creates real or real-like situations in which the language can be used. This enables students to communicate in English outside the classroom. During the CLT lesson, the teacher often plays important role of facilitator who facilitates activities to work with the target language.

\section{The Teaching Of Grammar In Bangladesh}

A few studies have been made in Bangladesh to find out the status of grammar in Bangladeshi schools. English is a compulsory subject in Bangladeshi schools and colleges. Students get enough time and opportunity to learn English for several years. At the S.S.C. level students have the same syllabus prepared by National Curriculum and Textbook Board (NCTB) to complete in class IX-X. After these two years, students sit for the S.S.C. examination. At the S.S.C. level English covers 200 marks. There are two papers of English at this level - Paper I and Paper II. There are some fixed items of grammatical rules to teach students in different education levels as mentioned in the syllabus. It depends on the teachers how they will teach the students. According to the NCTB syllabus, "In itself, however, a syllabus cannot ensure that communicative teaching and learning takes place in the classroom. It can only provide a set of criteria which, if properly implemented, would give the best possible change for that to happen." In a syllabus of grammar the topics and themes have been introduces as vehicles for practicing the four skills of listening, speaking, reading and writing. But the question is whether the students are able to acquire the skills of English language or the teachers are able to teach them properly.

Rahman (1988) implies the fact saying, Students do not know English at all. Most of them learn or at least make half-hearted effort to learn the rules that govern the grammar of the language. They have an uncertain grasp of structure marred further by inappropriate vocabulary and archaic usage.

Quader (1995-96, p.22-23) indicates the aspect of students' grammatical knowledge saying, “...they generally know most of the rules of grammar fluently. If asked to identify a particular rule they will mouth it flawlessly. But if they are asked to explain what differences the rule makes in the use of language, e.g. differences in meaning conveyed in the use of each tense, they are quite unsure. They are also unable to create grammatically correct texts of length required academically ..."

Islam (1997) describes the condition of teaching English grammar in Bangladesh saying that the teachers here use the grammar translation method of teaching and they rarely have the exposure to communicative approach of teaching. There is no contextual interpretation of grammatical rules. Some limited grammatical rules are taught in the classroom and students are asked to translate from Bengali to English and to write paragraph or to do writing tasks. After learning grammar in this way, students can neither communicate in written nor in the spoken form of the language.

According to the communicative language teaching, language teachers should teach the rules of grammar inductively. But Hasina (2002, p.166-167), in her research, finds out the fact that, "most of them teach the rules of grammar deductively, through direct demonstration in the classroom. And the students are taught to memorize the rules of English grammar."

The importance of teaching and learning English grammar has decreased both to the teachers and to the students. Sometimes they neglect the study of English grammar. They are more or less careful about the elements of grammar which are essential to answer the test items. They are not conscious of acquiring the sufficient grammatical knowledge essential for communicative function.

\section{Study Of The Researcher}

The aims and objectives of the empirical investigation of this research are to study and find out the causes of the ineffectiveness of teaching English grammar at the S.S.C. level in Bangladeshi schools and to analyze them in order to find out the solution. For this purpose an empirical investigation has been carried out on the teaching techniques, students' and teachers' mentalities, likings and dislikings, and the environment of the classroom - as all these factors are related to both language teaching and language learning situations. The aims and objectives can be pointed out like:

- $\quad$ studying the causes of the ineffectiveness of teaching English grammar in Bangladeshi schools;

- $\quad$ finding out status of CLT in teaching grammar and

- observing what teaching and learning situations exist in the schools.

In this regard the research question was: Is English grammar taught in Bangladesh in an effective communicative way? 
The aim of the researcher was to discover the causes of the ineffectiveness of teaching English grammar at the S.S.C. level in Bangladeshi schools. The specific objective was to observe what teaching and learning situations exist in the schools. The researcher selected six schools in the urban, semi-urban and rural levels to find out what is going on in the grammar classes at the S.S.C. level in Bangladeshi schools. Research group was founded with the English teachers and students of S.S.C. level English grammar classes in six schools in the urban, semiurban and rural levels of Bangladesh. The main research instruments were: 1) questionnaire for students; 2) questionnaire for teachers and 3) observation checklist. Instruments for the research were designed and administrated with care. All these methods were used for the survey to ensure accuracy, authenticity, validity and reliability of the data collection.

\section{Overall Assessment Of Data Analysis}

The researcher has studied and observed several factors related to the teaching and learning of English grammar at the S.S.C. level in Bangladeshi schools. The researcher has also tried to learn about the teaching methods, the materials used in teaching and learning, the classroom environment in the schools in different social set ups and few other things related to them.

In the questionnaire, most of the questions were selected to collect appropriate data from the people involved. Data were both qualitative and quantitative in nature. The researcher wanted to collect data from schools of three different social set-ups to get a varied picture of the teaching-learning situations.

Below, there is a summary regarding the students and their learning grammar as found by the researcher:

- Most of the students are not interested in learning English grammar.

- Students are not willing to practise at all.

- The students, who are advanced, mainly in urban and semi-urban level schools, learn by themselves without depending on the classroom teaching.

- Students are not motivated to learn grammar.

The important points about the teachers are summed up below:

- Teachers teach following the traditional Grammar Translation method. Teaching is mostly lecture based.

- Teachers do not arrange enough practice for the students.

- Teachers are not well trained.

- Teachers are unable to make the class interesting.

The researcher would like to sum up the main points of the classroom observation as follows:

- Classroom environment is not suitable for teaching and learning.

- The number of students in most of the classrooms is so large that it hampers the learning situation.

- Time of class is not enough to learn and practise properly.

- There is no use of audio visual materials to make the class effective and enjoyable.

The researcher had one research question. In relation to the question, the researcher found that many factors are responsible for the ineffectiveness of teaching grammar at the S.S.C. level in Bangladeshi schools. Among these, lack of awareness and interest for teaching and learning English grammar among teachers and students, unfavorable classroom environment, use of traditional methods of teaching, lack of teacher training are the important points which can be mentioned.

Therefore, the hypotheses of the research formed by the researcher are justified as the researcher has found them similar with the real situation through her studies, survey and observation. Other factors that have been mentioned above are responsible as well for the ineffectiveness of teaching grammar at the S.S.C. level in Bangladeshi schools. The effective teaching of English grammar at the S.S.C. level may be ensured by the right kind of attitude towards teaching and learning it. It has to be ensured that teachers implement their knowledge achieved through proper training. New teaching methods have to be introduced. A suitable classroom environment is to be built. Classes should be interesting so that the students get motivated to learn English grammar. Moreover, awareness should be raised in teaching and learning English grammar.

\section{Limitations}

The researcher faced some problems in conducting the research work. The researcher had to make the whole procedure clear to the teachers and to the students. Sometimes, mainly in rural schools, it was very difficult. It was not possible to interview the students as the number of the students was very large in each school. The guardians were not available for interview. So the researcher could not interview the guardians. Despite these problems, the researcher tried her best to maintain the validity and reliability of the research. 


\section{Conclusion}

From the above studies and discussion it is found that English grammar is not taught effectively in Bangladesh following communicative method. Regarding the main reasons lack of awareness and interest for teaching and learning English grammar among teachers and students, use of traditional methods of teaching, lack of teachers' training are mentionable. Effective grammar teaching in a communicative way can be ensured through the right kind of attitude towards teaching and learning it. New teaching methods can be introduced. Interesting communicative practices should be applied. Moreover awareness should be created regarding teaching and learning English grammar in an effective communicative method.

\section{Work Cited}

[1]. Antony, P. (1995). System in English Grammar: An Introduction for Language Teachers VII

[2]. Crystal, D. (1995). The Cambridge Encyclopedia of the English Language 88: 155-158: 191. Cambridge: Cambridge University Press.

[3]. Hasina, M. (2002). 'An Evaluation of the Teaching Method of English and the Testing System at the Secondary Level in Bangladesh.' 166-167

[4]. Islam, A.K.M. Waliul. (1997). 'Should English Grammar be Taught in Bangladesh?' Journal of the Institute of Modern Language Vol : 1 No: 1, June. 24-25

[5]. Palmer, F. (1971). Gramamr. Oxford University Press.

[6]. Penny, Ur. (1988). Grammar Practice Activities 4. Cambridge: Cambridge University Press.

[7]. Penny, Ur. (1991). Course in Language Teaching: Practice Theory 83. Cambridge: Cambridge University Press.

[8]. Quader, D. A. (1995-96). 'Need for the Use of Tasks in Our Classrooms.' Journal of the Institute of Modern Language 22, 23.

[9]. Rahman, A. (1988). 'English Language Teaching in Bangladesh : Problems and Prospects.' Journal of the Institute of Modern Language 95 . No. 3. July

[10]. Thornbury, S. (1999). How to Teach Grammar 1: 12: 15-18: 21-22: 23-25: 29: 111: 116: 119. England: Pearson Education Limited. 